\title{
The measurement of serum thyroxine in children
}

\author{
JENNIFER RYNESS \\ From the Department of Chemical Pathology, Hospital for Sick Children and Institute of Child Health, \\ London
}

SYNOPSIS A competitive protein-binding method was used to determine serum thyroxine concentration throughout childhood, adolescence, and in young adults. The values showed a gradual decrease as the child became older and reached adult levels by the time of adolescence. The range (mean $\pm 2 \mathrm{SD} \mu \mathrm{g} / 100 \mathrm{ml}$ ) for cord serum was $8 \cdot 8-14 \cdot 8$; for 4 weeks to 11 years, $6 \cdot 5-13 \cdot 9$; for 11 to 17 years, $5 \cdot 4-12 \cdot 2$, and for young adults $6 \cdot 0-11 \cdot 2$.

The measurement of serum thyroxine provides a valuable index of thyroid function, and with the introduction of the competitive protein-binding method by Ekins (1960) and the subsequent development of the assay, its determination has been simplified. Many workers have shown its use in diagnosis in adults (Murphy, Pattee, and Gold, 1966; Arango, Mayberry, Hockert, and Elveback, 1968; Ekins, Williams, and Ellis, 1969; Howorth and Maclagan, 1969).

The technique can easily be adapted to estimate the thyroxine content of small samples and therefore seems particularly suited to the study of thyroid function in children. In this paper, a protein-binding method based on that of Maclagan and Howorth (1969) is described and the results of thyroxine determinations in 145 'normal' subjects with ages ranging from the neonatal period to young adulthood are reported.

\section{Subjects}

Blood samples were obtained from (1) 114 children and adolescents who were undergoing investigation in the Hospital for Sick Children and in whom there was no clinical evidence of thyroid disease nor any other factor causing alteration in thyroxine-binding protein levels; (2) 11 healthy young adults aged 20 to 27 years; (3) 20 cord bloods obtained from full-term deliveries; and (4) six children being treated with L-thyroxine.

\section{Materials and Methods}

Serum thyroxine was determined by the proteinReceived for publication 3 May 1972. binding method of Maclagan and Howorth (1969) with minor modifications. Dried human plasma was reconstituted and stored in small fractions at $-20^{\circ} \mathrm{C}$ to provide a convenient source of thyroxine-binding globulin (TBG) for the assay. A $1.5 \%$ solution of TBG and ${ }^{125} \mathrm{I}$ thyroxine solution containing approximately 75000 counts per 10 ) seconds per $\mathrm{ml}$ were prepared in barbitone buffer as required. Serum (or plasma), $\mathbf{0 . 2} \mathrm{ml}$, was extracted with $1 \mathrm{ml}$ extraction fluid and duplicate aliquots of extract and of thyroxine standards (0-20 ng) were processed. Following resin uptake with Amberlite IRA $400\left(\mathrm{Cl}^{-}\right)$resin, $1 \mathrm{ml}$ of supernatant was removed and the radioactivity determined. A standard curve was drawn of percentage radioactivity bound to protein against the amount of thyroxine, and from this the thyroxine content of the unknown samples was calculated.

Protein-bound iodine (PBI) was estimated as described by Edwards and McCracken (1967).

Student's $t$ test was used to test differences between mean values of subgroups. The correlation coefficient was calculated from the regression line of the PBI values plotted against thyroxine iodine values.

\section{Results}

Thyroxine determinations were performed in duplicate unless otherwise indicated.

EVALUATION OF THE COMPETITIVE PROTEINBINDING METHOD

Details of recovery and precision studies are given in Table I. Number of batches implies the number of separate occasions on which the particular assay was performed.

The recovery from the extraction procedure was 


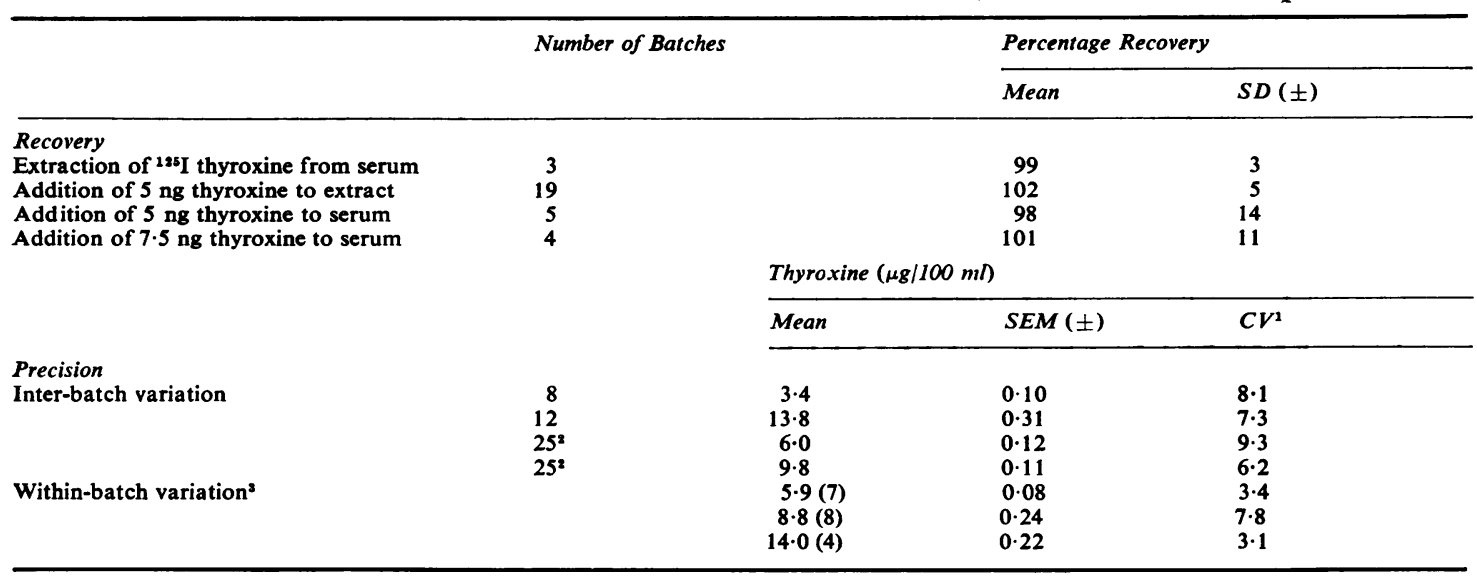

Table I Evaluation of competitive protein-binding method

${ }^{1} \mathrm{CV}=\mathrm{SD} \times 100 \times$ mean $^{-1}$

${ }^{2}$ Control sera (Dade, Florida) were used over a three-month period

${ }^{3}$ Numbers of determinations are shown in brackets.

assessed by adding ${ }^{125} \mathrm{I}$ thyroxine in trace amounts to serum and determining the radioactive content of aliquots of the extract. Five ng thyroxine was added to the extract with an endogenous thyroxine content of $7.4 \mathrm{ng}$, and recovery was assessed by expressing the observed increment of the thyroxine value as a percentage of that added. Similarly, $5 \mathrm{ng}$ or $7.5 \mathrm{ng}$ thyroxine was added to serum with endogenous thyroxine content of $5 \mathrm{ng}$.

The coefficients of variation were calculated for replicate determinations (a) within a single batch, and (b) between successive batches.

SERUM THYROXINE VALUES IN NORMAL

CHILDREN AND YOUNG ADULTS

Individual values for serum thyroxine are shown in
Figure 1. No sex difference was observed. Mean values $( \pm$ SD) for different groups are shown in Table II.

\begin{tabular}{llll}
\hline & $\begin{array}{l}\text { No. of } \\
\text { Patients }\end{array}$ & \multicolumn{2}{l}{ Thyroxine $(\mu \mathrm{g} / 100 \mathrm{ml})$} \\
\cline { 3 - 4 } & & Mean & $S D( \pm)$ \\
\hline Cord serum & 20 & $11 \cdot 8$ & $1 \cdot 5$ \\
4 weeks to 11 years & 79 & $10 \cdot 2$ & 1.9 \\
11 years to 17 years & 23 & $8 \cdot 8$ & $1 \cdot 7$ \\
Adults & 11 & $8 \cdot 6$ & $1 \cdot 3$ \\
\hline
\end{tabular}

Table II Serum thyroxine in childhood and adolescence

Correlation of thyroxine iodine values with $P B I$ determinations

Thyroxine iodine (thyroxine value $\times 0.653$ ) and PBI

Fig. 1 Individual serum thyroxine values throughout childhood and adolescence.

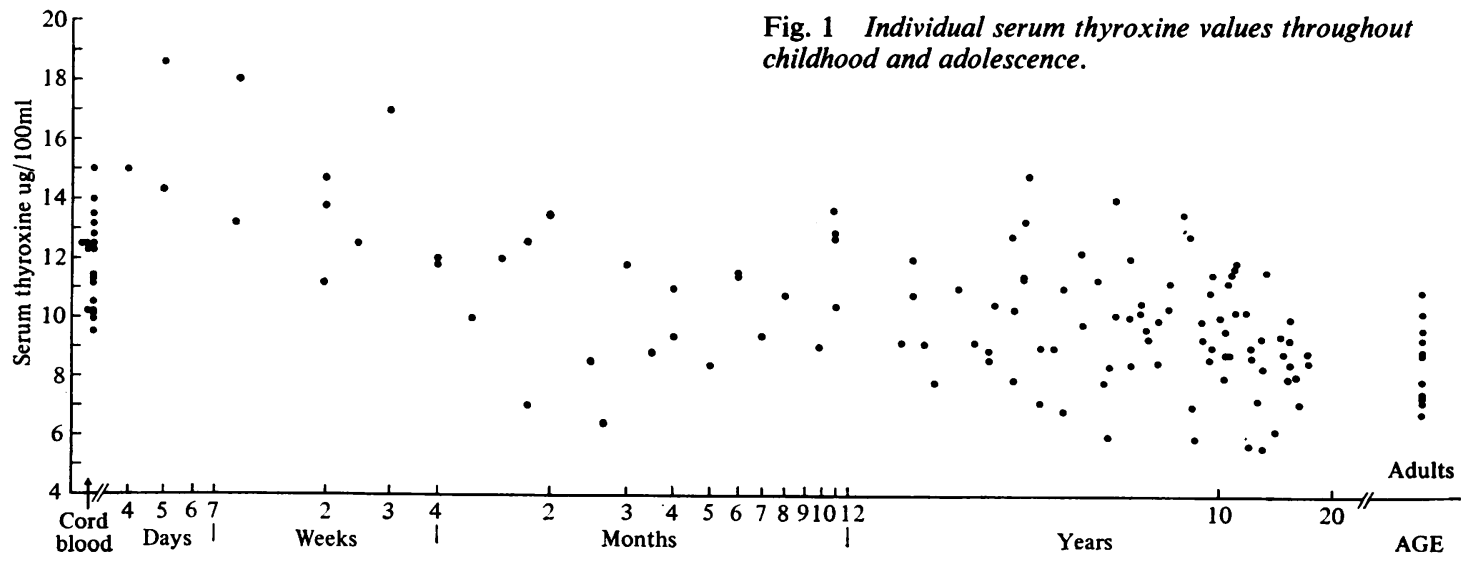


values were determined in a total of 50 patients including six receiving treatment with L-thyroxine. The correlation coefficient was $0.56(\mathrm{P}<0.001)$.

\section{Discussion}

The method is simple, specific, and reliable, and uses only a microsample of serum. The only compounds which interfere with it, other than analogues of thyroxine and tri-iodothyronine, are phenylbutazone and diphenylhydantoin (Ekins et al, 1969). Unlike the method for PBI, serum thyroxine determination by competitive protein binding is not affected by excess iodide, iodine-containing compounds, and mercurial diuretics.

There have been many studies on normal ranges of serum thyroxine for adult populations. The range obtained from this study on a group of 11 young adults of 6.0 to $11.2 \mu \mathrm{g} / 100 \mathrm{ml}$ (mean $\pm 2 \mathrm{SD}$ ) agrees closely with those reported by Murray, Joasoo, and Parkin (1971), by Nakajima, Kuramochi, Horiguchi, and Kubo (1966), and by Nusynowitz and Waliszewski (1969).

Few accounts have been devoted to values found in children. Arango et al (1968) included in their series patients aged between 10 and 20 years. No statistically significant trend with age was noted. Murray et al (1971), in a more extensive study of Australian children aged between 6 months and 15 years, recorded a gradual fall in serum thyroxine with increasing age and the present study confirms this observation. The mean values obtained here are all slightly lower than the values for the corresponding age groupings of Murray et al (1971) (Table III), the difference being significant only in the $6 \mathrm{mth}$ to 6 year group $(P<0.05)$.

We have extended the age range to include samples taken from cord blood obtained at delivery from 20 full-term infants, 11 children aged between 4 weeks and 6 months, and nine adolescents aged between 15 and 17 years. Results for cord serum (mean value $11.8 \pm 1.5(\mathrm{SD}) \mu \mathrm{g} / 100 \mathrm{ml}$ ) agree with those reported by Robin, Reketoff, Fang, and Selenkow (1969) and
Fisher, Odell, Hobel, and Garza (1969). SierzbaekNielsen and Mølholm Hansen (1967) and Malkasian and Mayberry (1970) record wider ranges in their studies. The values for a few children studied during the first week of life (Fig. 1) were significantly higher than either the range for cord serum or for the 4week to 6-month age group. This indication of hyperactivity of the thyroid gland in the neonatal period has been well documented with respect to levels of PBI (Fisher and Oddie, 1964) and has also been noted using the competitive protein-binding method for serum thyroxine (Sierzbaek-Nielsen and Molholm Hansen, 1967). Mean values obtained in the present study for several age groupings (Table II) showed significant differences between the values for cord serum and children older than 4 weeks $(P<0.005)$, and between pre-pubertal children and adolescents $(P<0.005)$.

Serum thyroxine values expressed as thyroxine iodine were usually found to be higher than the corresponding PBI values. This was observed also by Murray et al (1971). Children on thyroxine therapy often gave high values.

Non-thyroidal factors may reduce the circulating level of thyroxine (tri-iodothyronine diphenylhydantoin) or cause alterations in TBG levels as in inherited TBG abnormalities, nephrotic syndrome, and malnutrition. In such situations, the total serum thyroxine value may give a misleading indication of the individual's thyroid status, and a measure of the concentration of thyroxine-binding proteins is necessary. This may be achieved either by direct (Sterling and Brenner, 1966) or indirect measurement (Maclagan and Howorth, 1969) of the free thyroxine fraction which is inversely proportional to the concentration of binding proteins.

I should like to thank Mr R. Elliot of the Department of Chemical Pathology, Westminster Hospital, for assistance in setting up the standard method described; the physicians and surgeons of the Hospital for Sick Children for allowing me to study their patients; the physicians of Queen Mary's

\begin{tabular}{|c|c|c|c|c|c|c|}
\hline \multirow[t]{3}{*}{ Age Group } & \multicolumn{3}{|l|}{ This Studv } & \multicolumn{3}{|c|}{ Murray et al (197I) } \\
\hline & \multirow[t]{2}{*}{ No. of Patients } & \multicolumn{2}{|c|}{ Thyroxine $(\mu \mathrm{g} / 100 \mathrm{ml})$} & \multirow[t]{2}{*}{ No. of Patients } & \multicolumn{2}{|c|}{ Thyroxine $(\mu \mathrm{g} / 100 \mathrm{ml})$} \\
\hline & & Mean & $S D( \pm)$ & & Mean & $S D( \pm)$ \\
\hline $\begin{array}{l}0.5 \text { to } 6 \text { years } \\
6 \text { to } 12 \text { years } \\
12 \text { to } 15 \text { years } \\
\text { Adults }\end{array}$ & $\begin{array}{l}42 \\
30 \\
15 \\
11\end{array}$ & $\begin{array}{r}10 \cdot 3 \\
10 \cdot 0 \\
8 \cdot 4 \\
8 \cdot 6\end{array}$ & $\begin{array}{l}2 \cdot 0 \\
1 \cdot 6 \\
1 \cdot 6 \\
1 \cdot 3\end{array}$ & $\begin{array}{l}70 \\
80 \\
30 \\
-\end{array}$ & $\begin{array}{r}11 \cdot 4 \\
10 \cdot 7 \\
9 \cdot 5 \\
9 \cdot 1\end{array}$ & $\begin{array}{l}1 \cdot 9 \\
2 \cdot 0 \\
1 \cdot 8 \\
1 \cdot 3\end{array}$ \\
\hline
\end{tabular}

Table III Comparison of results with those obtained by Murray et al (1971) 
Hospital, Sidcup, Kent, for samples from cord blood and from neonates, kindly arranged by Dr Paul Whiteman; Professor Barbara Clayton for facilities in her Department and for her encouragement and guidance; Dr R. W. H. Edwards for valuable advice and assistance; and Mrs Shelia Atherden for PBI determinations and considerable help.

The work was supported by a grant from the Joint Research Board of the Hospital for Sick Children and the Institute of Child Health.

\section{References}

Arango, G., Mayberry, W. E., Hockert, T. J., and Elveback, L. R. (1968). Total and free human serum thyroxine in normal and abnormal thyroid states. Mayo Clin. Proc., 43, 503-516.

Edwards, R. W. H., and McCracken, J. H. (1967). Glove box system for micro-determination of protein-bound iodine in children's blood. J. clin. Path., 20, 302-303.

Ekins, R. P. (1960). The estimation of thyroxine in human plasma by an electrophoretic technique. Clin. chim. Acta, 5, 453-459.

Ekins, R. P., Williams, E. S., and Ellis, S. (1969). The sensitive and precise measurement of serum thyroxine by saturation analysis (competitive protein binding assay). Clin. Biochem., 2, 253-288.

Fisher, D. A., and Oddie, T. H. (1964). Neonatal thyroidal hyperactivity. Amer. J. Dis. Child., 107, 574-581.

Fisher, P. A., Odell, W. D., Hobel, C. J., and Garza, R. (1969). Thyroid function in the term fetus. Pediatrics, 44, 526-535.
Howorth, P. J. N., and Maclagan, N. F. (1969). Clinical application of serum-total-thyroxine estimation, resin uptake, and free thyroxine index. Lancet, 1, 224-228.

Maclagan, N. F., and Howorth, P. J. N. (1969). Thyroid function studies using resin uptake of radioactive thyronines from serum and total thyroxine assay; the free thyroxine index. Clin. Sci., 37, 45-60.

Malkasian, G. D., and Mayberry, W. E. (1970). Serum total and free thyroxine and thyrotropin in normal and pregnant women, neonates, and women receiving progestogens. Amer. J. Obstet. Gynec., 108, 1234-1238.

Murphy, B. E. P., Pattee, C. J., and Gold, A. (1966). Clinical evaluation of a new method for the determination of serum thyroxine. $J$. clin. Endocr., 26, 247-256.

Murray, I. P. C., Joasoo, A., and Parkin, J. (1971). In-vitro thyroid tests in children. Med. J. Aust., 1, 77-79.

Nakajima, H., Kuramochi, M., Horiguchi, T., and Kubo, S. (1966). $A$ new and simple method for the determination of thyroxine in serum. J. clin. Endocr., 26, 99-103.

Nusynowitz, M. L., and Waliszewski, J. (1969). Simplification of determination of serum thyroxine iodine by competitive binding analysis. Amer. J. Roentgenol., 106, 791-793.

Robin, N. I., Reketoff, S., Fang, V., and Selenkow, H. A. (1969). Parameters of thyroid function in maternal and cord serum at term pregnancy. J. clin. Endocr., 29, 1276-1280.

Siersbaek-Nielsen, K., and Mølholm Hansen, J. (1967). Thyroid function and plasma tyrosine in the neonatal period. Acta paediat. scand., 56, 141-150.

Sterling, K., and Brenner, M. A. (1966). Free thyroxine in human serum: simplified measurement with the aid of magnesium precipitation. J. clin. Invest., 45, 153-163. 